DOI: $10.19195 / 2084-5065.46 .5$

\title{
Cel(e) wykonywania kary pozbawienia wolności a instytucja warunkowego przedterminowego zwolnienia (uwagi na marginesie uchwały Sądu Najwyższego z dnia 26 kwietnia 2017 r., I KZP 2/17')
}

\author{
AgniesZKa Kania \\ Katedra Prawa Karnego i Postępowania Karnego \\ Wydział Prawa i Administracji Uniwersytetu Zielonogórskiego
}

Cel kary a funkcja kary — wprowadzenie w problematykę

W rozważaniach penologicznych trafnie zwrócono uwagę na potrzebę odróżnienia funkcji kary od celu kary ${ }^{2}$. O ile bowiem funkcja kary po-

\footnotetext{
1 Uchwała SN z 26 kwietnia 2017 r., LEX nr 2275714.

2 Należy jednak wspomnieć, że określenie relacji pomiędzy pojęciami „cel kary” i ,funkcja kary” wywołało w piśmiennictwie pewne rozbieżności interpretacyjne. Do ich powstania przyczyniło się niewątpliwie dokonane w doktrynie wyróżnienie: 1) funkcji postulatywnej, utożsamianej z celem kary, co należałoby uznać za zbędny zabieg interpretacyjny, oraz 2) funkcji rzeczywistej, odnoszącej się w założeniu do faktycznych następstw wywołanych przez karę. Wydaje się, że zaprezentowane tutaj ujęcie problemu nie jest właściwe, gdyż w istocie generuje niepotrzebne wątpliwości w ramach powszechnie zaaprobowanej już terminologii. Zob. P. Petasz, Sens, istota i cele kary kryminalnej, „Gdańskie Studia Prawnicze” XIV, 2005, s. 1124. Zob. także w tym zakresie M. Cieślak, O węzłowych pojęciach związanych z sensem kary, „Nowe Prawo” 1969, nr 2, s. 202.
}

Nowa Kodyfikacja Prawa Karnego 46, 2017

(C) for this edition by CNS 
siada charakter obiektywny, związany z rzeczywistym jej oddziaływaniem $^{3}$, o tyle cel kary skupia już w sobie pewne subiektywne założenia, wyrażając tym samym postulowane, czy też, inaczej mówiąc, pożądane stany rzeczy, których realizacja mogłaby nastąpić dzięki instrumentowi kontroli społecznej, w postaci kary kryminalnej. W tym więc znaczeniu cel kary posiada charakter pierwotny w stosunku do planowanego efektu, który zamierza się osiągnąć za jej pośrednictwem.

Na podstawie powyższego, ogólnie aprobowanego w piśmiennictwie, rozróżnienia celu kary i jej funkcji należałoby dopowiedzieć, że wzajemna relacja pomiędzy tymi pojęciami jest, ujmując to nieco metaforycznie, „w przybliżeniu taka, jak między ideą społeczną a rzeczywistością

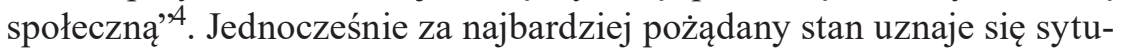
ację, gdy pomiędzy celami i funkcjami kary zachodzi jak najdalej idąca zbieżność 5 .

\section{Cel(e) kary pozbawienia wolności}

Problematyka określenia celów kary kryminalnej pojawia się we wszystkich stadiach jej konkretyzacji, począwszy od ustawowego zagrożenia, przez jej wymiar sądowy, aż po wykonanie. Koncentrując się w niniejszych analizach na zagadnieniu celów, realizowanych przez jedną z kar przewidzianych w polskim prawie karnym, tj. karę pozbawienia wolności, wypadałoby w pierwszej kolejności zaznaczyć, że na etapie sądowego wymiaru kary zagadnienie to odzwierciedla w sposób szcze-

Z perspektywy ogólnoteoretycznej zob. także I. Bogucka, O pojęciu ,funkcja prawa”, „Państwo i Prawo” 1990, nr 9, s. 50 n.

3 W odniesieniu do kary pozbawienia wolności J. Warylewski wskazuje zarówno na jej funkcje negatywne (wymieniając w tym zakresie funkcję kryminogenną oraz demoralizującą), jak i pozytywne (wyróżniając tutaj funkcje: subsydiarną, ekspresyjną, izolacyjną, gwarancyjną, afirmującą, kompensacyjną, sprawiedliwościową, zapobiegawczą oraz resocjalizacyjną). Zob. J. Warylewski, O wybranych funkcjach i celach kary pozbawienia wolności, [w:] Wykonywanie kary pozbawienia wolności $w$ Polsce - w poszukiwaniu skuteczności, red. H. Machel, Gdańsk 2006, s. 21-23. Zob. także M. Kuć, Indywidualizacja wykonywania kary pozbawienia wolności, Lublin 2007, s. 82.

4 A. Krukowski, Problemy zapobiegania przestepczości, Warszawa 1982, s. 128-129.

5 J. Warylewski, Prawo karne. Część ogólna, Warszawa 2015, s. 68. 
gólny dyrektywalna regulacja art. $53 \S 1$ k.k., wskazująca (in genere) na obecność w tym procesie celu sprawiedliwościowego, indywidualno- oraz ogólnoprewencyjnego ${ }^{6}$. Warto przy tym podkreślić, że na wspomnianej płaszczyźnie konkretyzacji sankcji karnej ustawodawca nie wskazał, aby którykolwiek z wymienionych celów miał w istocie charakter wiodący. Zabieg ten wydaje się w pełni uzasadniony, gdyż - jak przekonująco dowiedziono w piśmiennictwie — trudno byłoby in abstracto nadać priorytetową rolę jednemu $\mathrm{z}$ wyróżnionych w tym przepisie celów ${ }^{7}$.

Podejmując natomiast próbę określenia celów wspomnianej kary z perspektywy karnowykonawczej ${ }^{8}$, należałoby zauważyć, że ustawodawca na

${ }^{6} \mathrm{~W}$ świetle regulacji art. $53 \S 1$ k.k. cel sprawiedliwościowy wiązany jest tradycyjnie z dyrektywą stopnia winy oraz stopnia społecznej szkodliwości czynu, cel indywidualnoprewencyjny z wychowawczym i zapobiegawczym oddziaływaniem kary na sprawcę, a z kolei cel ogólnoprewencyjny z potrzebą kształtowania świadomości prawnej społeczeństwa. Zob. także wyrok SA w Krakowie z 7 czerwca 2016 r., II AKa 101/16, LEX nr 2179314, w którym stwierdzono, że: „Cele kary zasadniczo można podzielić na: prewencję ogólną (zapobiegawcze oddziaływanie na społeczeństwo), prewencję indywidualną (zapobiegawcze oddziaływanie na jednostkę) i sprawiedliwościową (odpłatę za popełnione przestępstwo). Istotą kary kryminalnej jest dolegliwość, która musi być dolegliwością celową i zamierzoną [...]. Stosowanie kar pozbawienia wolności jest uzasadnione poprzez racje utylitarne i moralne. Do najważniejszych funkcji kary pozbawienia wolności zalicza się: /a/ funkcję izolacyjną [...]; /b/ funkcję odstraszającą innych przed popełnieniem przestępstwa; /c/ funkcję odwetową ze swoistą odpłatą społeczeństwa za popełnione zło; /d/ funkcję kompensacyjną — [...] umożliwienie naprawienia wyrządzonego zła; /e/ funkcję poprawczą poprzez działania na rzecz poprawienia skazanego".

${ }^{7}$ Zob. przede wszystkim: T. Kaczmarek, Teoretyczne i praktyczne aspekty sporu co do hierarchii ogólnych dyrektyw sądowego wymiaru kary, ,Zeszyty Naukowe Instytutu Badania Prawa Sądowego" 1980, nr 13, s. 26; J. Giezek, [w:] Kodeks karny. Część ogólna. Komentarz, red. J. Giezek, Warszawa 2012, s. 389-390; Z. Sienkiewicz, Spoteczne niebezpieczeństwo czynu jako dyrektywa sadowego wymiaru kary (na tle teorii i praktyki sadowej), Wrocław 1977, s. 95-96, a także wyrok SN z 11 maja 1972 r., Rw 331/71, OSNKW 1972, nr 9, poz. 145, w którym stwierdzono, że: „Przepis art. 50 § 1 k.k. (obecnie art. $53 \S 1$ k.k.) formułuje i zawiera generalne dyrektywy w zakresie wymiaru kary, przy czym brak podstaw do zasadnego twierdzenia, że któraś z nich jest główną, nadrzędną w stosunku do pozostałych. Każda $\mathrm{z}$ tych dyrektyw jest równorzędna".

${ }^{8}$ Warto przypomnieć, że w piśmiennictwie karnowykonawczym wskazano: „Cele wykonywania kary [...] nie stanowią w żadnym wypadku intelektualnej konstrukcji wymyślonej przez komisję przygotowującą obowiązujący k.k.w. Są one pochodną wielu czynników, wśród których należy zwłaszcza wymienić: tradycję polskiego prawa karne- 
tym etapie konkretyzacji sankcji karnej przyjął zgoła odmienną optykę. Już bowiem z samego brzmienia art. 67 k.k.w. można prima facie wywnioskować o normatywnie wskazanej preponderancji celu indywidualnoprewencyjnego w procesie wykonywania kary pozbawienia wolności ${ }^{9}$. Stąd też nie bez przyczyny konstatuje się w doktrynie przedmiotu, że o ile właściwym momentem dla realizacji celów sprawiedliwościowych oraz ogólnoprewencyjnych jest moment wymierzania kary, o tyle postępowaniu wykonawczemu przypada zasadnicza, a de facto wiodąca rola w zakresie urzeczywistnienia jej readaptacyjnych zadań ${ }^{10}$. Nie deprecjonując w żaden sposób (do czego mogłyby prima facie skłaniać powyższe stwierdzenia) roli względów indywidualnoprewencyjnych na etapie sądowego wymiaru kary (w czym expressis verbis utwierdza regulacja art. $53 \S 1$ k.k., odwołująca się do „celów zapobiegawczych lub wychowawczych”), trzeba jednak podkreślić, że przez sam akt sądowego jej wymiaru trudno jest zbudować czy osiągnąć prospołeczne nastawienie sprawcy ${ }^{11}$. Nieco metaforycznie rzecz ujmując, można by w istocie stwierdzić, że w jurysdykcyjnej fazie konkretyzacji kara pozbawienia wolności uzyskuje

go, doświadczenia praktyki oraz doświadczenia innych krajów europejskich szczególnie zaawansowanych w rozwoju penitencjarystyki oraz stanowisko ważnych dokumentów międzynarodowych ustalających reguły postępowania z więźniami” - T. Szymanowski, [w:] T. Szymanowski, Z. Świda, Kodeks karny wykonawczy. Komentarz, Warszawa 1998, s. 146.

9 D. Sarzała, Resocjalizacyjny wymiar kary pozbawienia wolności, [w:] Kary dtugoterminowe. Polityka karna. Wykonywanie. Warunkowe zwolnienia, red. T. Gardocka, Warszawa 2006, s. 155; B. Nowak, Cele, funkcje i zasady wykonywania kary pozbawienia wolności i tymczasowego aresztowania, [w:] Zagadnienia penitencjarne, red. H. Chmielewska et al., Kalisz 2004, s. 55. W piśmiennictwie wskazuje się, że realizacja celu indywidualnoprewencyjnego następuje przez: odstraszanie, uniemożliwienie powrotu do przestępstwa oraz wychowanie - R. Kaczor, Kontrowersje wokót modelu dyrektywy prewencji indywidualnej, „Prokuratura i Prawo” 2007, nr 11, s. 92-93; P. Szczepaniak, Kara pozbawienia wolności a wychowanie, Kalisz-Warszawa 2003, s. 17-18.

10 T. Kalisz, Cele wykonywania kary pozbawienia wolności, „Nowa Kodyfikacja Prawa Karnego" VI, 2000, s. 219.

11 Samo dokonanie prawidłowej prognozy socjalnej sprawcy (na etapie sądowego wymiaru kary) wydaje się zresztą problematyczne. Zob. T. Kaczmarek, Z rozważań nad racjonalizacją sądowego wymiaru kary, [w:] Profesor Marian Cieślak — osoba, dzieło, kontynuacje, red. W. Cieślak, S. Steinborn, Warszawa 2013, s. 91.

Nowa Kodyfikacja Prawa Karnego 46, 2017

(C) for this edition by CNS 
wprawdzie status kary „poprawczej”, ale tylko „w nadziei”12. Trafnie więc ocenił T. Kaczmarek, że:

Kara na etapie jej orzekania nie daje programu ani odpowiedzi, jak należy zmieniać osobowość skazanego [...]. W rzeczy samej operacjonalizacja [...] „poprawczego” celu wymierzonej kary pozbawienia wolności, nie przesądzając jednocześnie jej wyniku, nastąpić może dopiero w zakładzie karnym, w którym dochodzi w ramach oddziaływania penitencjarnego już do bezpośredniej interakcji pomiędzy personelem wychowującym a skazanymi, dla których resocjalizacja jest prawem, a nie obowiązkiem ${ }^{13}$.

W powyższym stwierdzeniu słusznie zasygnalizowano, że samo wykonanie wyroku nie przekłada się per se na osiągnięcie poprawy sprawcy. Konieczne okazuje się zaistnienie pewnych zmian, przeobrażeń w postawie oraz psychice skazanego ${ }^{14}$.

Zgodnie z wcześniejszymi uwagami, na wspomnianej płaszczyźnie karnowykonawczej szczególna pozycja celu indywidualnoprewencyjnego została wskazana w treści przepisu art. 67 § 1 k.k.w., określającego zasadniczy (jeśli nie jedyny wręcz) cel wykonywania kary pozbawienia wolności ${ }^{15}$. Wobec normatywnego kształtu niniejszej regulacji, jak również intytulacji Oddziału I („Cele wykonywania kary”), zawartego w rozdziale X k.k.w., można by więc postawić pytanie, czy przepisy k.k.w., w myśl chociażby zapowiedzi, wynikającej z art. 71 k.k.w. (jak również z art. 73 k.k.w., wskazującego na ,zadania” kary pozbawienia

12 M. Porowski, Karanie a resocjalizacja, ,Studia Kryminologiczne, Kryminalistyczne i Penitencjarne" 1985, nr 16, s. 128.

13 T. Kaczmarek, Resocjalizacja sprawcy jako cel wymiaru i wykonania kary pozbawienia wolności, [w:] Prawo karne wykonawcze w systemie nauk kryminologicznych. Księga pamiątkowa ku czci Profesora Leszka Boguni, red. T. Kalisz, Wrocław 2011, s. 86; zob. także B. Janiszewski, Poprawcza funkcja kary pozbawienia wolności stosowanej wobec sprawców przestępstw nieumyślnych, ,Ruch Prawniczy, Ekonomiczny i Socjologiczny" 1979, nr 2, s. 65 n.

14 M. Porowski, op. cit., s. 136.

15 Słusznie wskazuje G.B. Szczygieł, że: „Oczekiwania związane z wykonywaniem kary pozbawienia wolności, zgodnie z art. $67 \S 1$ k.k.w., to poprawa skazanego. Program minimum to poprawa jurydyczna, a więc taka zmiana osobowości, która prowadzi do powstrzymania się od popełniania przestępstw po opuszczeniu więzienia. W programie maksimum spodziewany efekt to poprawa moralna więźnia” - G.B. Szczygieł, Cele wykonywania kary pozbawienia wolności - kilka refleksji, „Nowa Kodyfikacja Prawa Karnego" XLIII, 2017, s. 526-527. 
wolności ${ }^{16}$ ), spełniają także inne założenia ustawodawcy, które wykraczają poza potrzebę realizacji celu w postaci readaptacji skazanego oraz ochrony społeczeństwa przed przestępczością ${ }^{17}$. Z uwagi na specyfikę regulacji karnowykonawczych postawienie hipotezy o pluralizmie celów wykonania kary pozbawienia wolności, będących wprost swoistą

${ }^{16} \mathrm{~W}$ kontekście regulacji art. 73 k.k.w. stwierdza się, że przepis ten eksponuje zadanie, będące de facto celem wykonywania kary pozbawienia wolności, w postaci ochrony społeczeństwa przed przestępczością - G.B. Szczygieł, Kary dtugoterminowe a cele wykonywania kary pozbawienia wolności, [w:] Kary dtugoterminowe. Polityka karna. Wykonywanie. Warunkowe zwolnienia..., s. 225. Jednocześnie nie sposób zgodzić się z poglądem, że wyeksponowany w tym przepisie cel wykonywania kary pozbawienia wolności (art. 73 k.k.w.) odpowiada istocie celu ogólnoprewencyjnego - tak M. Kołyszko, Kara pozbawienia wolności i jej cele, [w:] Kowalski vs. Temida: oskarżony, ofiara czy skazany? Patologie wymiaru sprawiedliwości. Materiały z sesji naukowej Koła Naukowego Prawa Karnego i Kryminologii, red. K. Witkowska-Rozpara, Toruń 2009, s. 139-140.

17 P. Stępniak, Odroczenie wykonania kary jako przesłanka probacyjna, [w:] X lat obowiazywania Kodeksu Karnego Wykonawczego, red. S. Lelental, G.B. Szczygieł, Białystok 2009, s. 453. Warto w tym miejscu również nadmienić, że wyraźnym nawiązaniem do jednego z aspektów oddziaływania ogólnoprewencyjnego na płaszczyźnie karnowykonawczej pozostaje niewątpliwie treść regulacji art. 9 k.k.w. W myśl wspomnianego przepisu postępowanie wykonawcze wszczyna się niezwłocznie, gdy orzeczenie stało się wykonalne. Mając więc na uwadze, że wyrok staje się wykonalny z chwilą uprawomocnienia, w orzecznictwie podkreślono, że „wstrzymanie wykonania wyroku może nastąpić jedynie wyjątkowo, gdy ujawnią się okoliczności świadczące o tym, że bezzwłoczne podjęcie czynności wykonawczych pociągnie za sobą nieodwracalne i niepowetowane skutki dla skazanego" - postanowienie SN z 26 września 2012 r., V KK 218/12, LEX nr 1220962; postanowienie SN z 6 czerwca 2000 r., II KKN 74/99, LEX nr 50206; wyrok SN z 31 sierpnia 1971 r., V KRN 213/71, LEX nr 16627; postanowienie SN z 17 października 2013 r., V KK 271/13, LEX nr 1375780. Zob. także postanowienie SA w Krakowie z 26 września 2006 r., II AKzw 658/06, „Krakowskie Zeszyty Sądowe" 2006, nr 10, poz. 12; J. Kwaśniewski, Kara pozbawienia wolności $w$ świadomości społecznej oraz w świetle zasad sprawnego karania, „Archiwum Kryminologii” XXIX-XXX, 2007-2008, s. 699; Z. Świda, Właściwość sądu i prawo strony do rozstrzygania sprawy w ,rozsądnym terminie”, „Państwo i Prawo” 2005, nr 10, s. 47; J. Czapska, Spoleczne następstwa przewlekłości postępowania, [w:] Zagubiona szybkość procesu karnego. Jak ja przywrócić?, red. S. Waltoś, J. Czapska, Warszawa 2005, s. $213 \mathrm{n}$. W piśmiennictwie zastrzega się jednak, iż powyższa regulacja nie oznacza, że w ten sposób ustawodawca przesądził per se, iż cel ogólnoprewencyjny należy do celów wykonywania kary pozbawienia wolności. Zob. S. Lelental, Kodeks karny wykonawczy. Komentarz, Warszawa 2016, s. 334.

Nowa Kodyfikacja Prawa Karnego 46, 2017

(C) for this edition by CNS 
kontynuacją celów kary, uwzględnianych na moment wyrokowania, okazuje się tak ryzykowne, jak wątpliwe. Dostrzegając bowiem podkreślaną w przepisach k.k.w. wartość zindywidualizowanego oddziaływania na skazanych w ramach ustawowo przewidzianych systemów wykonywania kary, rodzajów oraz typów zakładów karnych ${ }^{18}$, trudno byłoby nie zgodzić się z poglądem, że wspomniany cel indywidualnoprewencyjny odsunął de facto inne cele penalne na daleki margines ${ }^{19}$.

Na podstawie dotychczasowych ustaleń należałoby stwierdzić, że cele leżące u podstaw wymierzania kary pozbawienia wolności ulegają wyraźnemu zawężeniu na płaszczyźnie jej wykonywania. W konsekwencji można by zatem skonstatować, że o ile wymiar kary pozbawienia wolności posiada charakter wielokierunkowy, o tyle etap jej wykonania jest już zorientowany jednokierunkowo ${ }^{20}$. Nie ulega przy tym wątpliwości, że prawidłowa realizacja tak ,wysublimowanego" na wspomnianym etapie postępowania celu indywidualnoprewencyjnego ${ }^{21}$ zależy od wielu czynników. Nie sposób byłoby bowiem pominąć faktu, że choć wzgląd na readaptacyjny cel wykonywania kary pozbawienia wolności - skupiający w sobie bogactwo problemów o doniosłości zarówno teoretycznej, jak i praktycznej — odgrywa ważką rolę w ramach kształtowania kierunków polityki penitencjarnej, to jednak jego urzeczywistnienie napotyka na pewne obiektywne przeszkody (np. w postaci niechęci samych skazanych, przeludnienia zakładów karnych, szeregu trudności natury materialnej), które finalnie mogą utrudniać, a niekiedy wręcz uniemożliwiać podjęcie właściwych i skutecznych oddziaływań o charakterze resocjalizacyjnym ${ }^{22}$.

${ }^{18}$ H. Machel, Więzienie jako instytucja karna i resocjalizacyjna, Gdańsk 2003, s. $45-48$.

19 W orzecznictwie podniesiono jednak, że „dalszym zadaniem wykonania kary pozbawienia wolności jest zrealizowanie innych, poza resocjalizacją sprawcy, celów kary, leżących u podstaw jej wymierzania: prewencji ogólnej i sprawiedliwej odpłaty" — postanowienie SN z 9 lutego 1995 r., II KRN 262/94, OSNKW 1995, nr 3-4, poz. 18.

20 J. Lachowski, [w:] Kodeks karny wykonawczy. Komentarz, red. J. Lachowski, Warszawa 2016, s. 362.

${ }^{21}$ I. Niewiadomska, Osobowościowe uwarunkowania skuteczności kary pozbawienia wolności, Lublin 2007, s. 56.

22 T. Kalisz, A. Kwieciński, Cele izolacji penitencjarnej w perspektywie odrzucenia idei przymusowej resocjalizacji, „Przegląd Prawa i Administracji” 2013, nr 95, s. 129.

Nowa Kodyfikacja Prawa Karnego 46, 2017

(C) for this edition by CNS 


\section{Warunkowe przedterminowe zwolnienie z odbycia kary pozbawienia wolności a problematyka celów kary}

Ogólnie niekwestionowana pozycja celu indywidualnoprewencyjnego na etapie wykonywania kary pozbawienia wolności ulega pewnemu zachwianiu, gdy prawdziwość tego założenia próbuje się odnieść do instytucji warunkowego przedterminowego zwolnienia, która - choć jest związana z fazą wykonywania kary pozbawienia wolności ${ }^{23}$ — to jednak podlega reżimowi nie tylko przepisów karnowykonawczych, lecz także przepisów kodeksu karnego. Zasygnalizowane w ten sposób swoiste „przepołowienie regulacyjne” wymienionej instytucji probacyjnej ${ }^{24}$ nakazuje przypomnieć $\mathrm{w}$ tym miejscu, że zgodnie z postanowieniami karnomaterialnymi (art. $77 \S 1$ k.k.):

Skazanego na karę pozbawienia wolności sąd może warunkowo zwolnić z odbycia reszty kary tylko wówczas, gdy jego postawa, właściwości i warunki osobiste, okoliczności popełnienia przestępstwa oraz zachowanie po jego popełnieniu i w czasie odbywania kary uzasadniają przekonanie, że skazany po zwolnieniu będzie stosował się do orzeczonego środka karnego lub zabezpieczającego i przestrzegał porządku prawnego, w szczególności nie popełni ponownie przestępstwa.

Zastanawiając się - w kontekście przytoczonego fragmentu przepisu — nad istotą cytowanej przesłanki, warunkującej skorzystanie z tej instytucji, wypadałoby, już z perspektywy samej wykładni językowej, zwrócić uwagę na znaczenie wyeksponowanej w treści art. $77 \S 1$ k.k. partykuły „tylko". Wydaje się bowiem, że sformułowanie to, w świetle omawianej regulacji, odgrywa podwójną rolę. Po pierwsze, wskazuje ono przesłanki, które sąd powinien ocenić przy ustalaniu tzw. pozytywnej prognozy kryminologicznej sprawcy, zawężając je de facto do tych, które wymieniono we wspomnianym przepisie, a po drugie - co w istocie stanowi konsekwencję powyższego stwierdzenia - pozwala na ocenę prognozy kryminologicznej tylko przez pryzmat okoliczności wyeksponowanych

23 Zob. S. Lelental, Warunkowe przedterminowe zwolnienie w projekcie kodyfikacji karnej, [w:] Problemy nauk penalnych. Prace ofiarowane Pani Profesor Oktawii Górniok, red. L. Tyszkiewicz, Katowice 1996, s. 113.

24 P. Wiktorska, Warunkowe przedterminowe zwolnienie z odbycia reszty kary pozbawienia wolności jako instytucja polityczno-kryminalna, [w:] Zmiany w prawie karnym wykonawczym w latach 2009-2014, red. A. Kwieciński, Warszawa 2014, s. 198-199.

Nowa Kodyfikacja Prawa Karnego 46, 2017

(C) for this edition by CNS 
w cytowanym przepisie art. $77 \S 1$ k.k. ${ }^{25}$ Pogląd ten, forsujący de facto bezkonkurencyjne znaczenie względów indywidualnoprewencyjnych przy zastosowaniu omawianej instytucji probacyjnej, nie uzyskał jednak pełnej aprobaty w praktyce wymiaru sprawiedliwości ${ }^{26}$. Jak można przypuszczać, źródłem pojawiających się w tym zakresie rozbieżności, a także kontrowersji pozostaje treść regulacji art. 56 k.k., w świetle której przepisy art. 53, art. $54 \S 1$ oraz art. 55 k.k. stosuje się odpowiednio przy orzekaniu innych środków przewidzianych w kodeksie karnym, z wyjątkiem obowiązku naprawienia wyrządzonej przestępstwem szkody lub zadośćuczynienia za doznaną krzywdę. Powstały w ten sposób, na kanwie art. 56 k.k., problem interpretacyjny wymagałby w rezultacie rozstrzygnięcia, czy przy orzekaniu w przedmiocie warunkowego przedterminowego zwolnienia sąd powinien kierować się wyłącznie względami indywidualnoprewencyjnymi z art. 77 § 1 k.k., czy też — w myśl art. 56 k.k. - uwzględnić „odpowiednio” również i inne cele penalne ${ }^{27}$.

$\mathrm{W}$ ramach niejednolicie prezentowanego $\mathrm{w}$ tym zakresie stanowiska judykatury oraz doktryny, z jednej strony, wyrażono pogląd, że zgodnie z zasadą lege non distinguente ustawowy zwrot, odnoszący się do ,innych środków przewidzianych w tym kodeksie", należy interpretować w sposób

25 J. Kulesza, Glosa aprobujaca do postanowienia Sądu Apelacyjnego w Warszawie z dnia 3 stycznia 1998 r., II AKz 115/98, „Palestra” 2000, nr 1, s. 179.

26 Zob. postanowienie SA w Szczecinie z 9 lutego 2012 r., II AKzw 60/12, KZS 2012, nr 9, poz. 56; postanowienie SA w Szczecinie z 20 października 2010 r., II AKzw 819/10, KZS 2011, nr 9, poz. 70; postanowienie SA w Gdańsku z 18 października 2000 r., II AKz 943/00, LEX nr 46424. Zob. jednak odmiennie m.in.: postanowienie SA w Białymstoku z 31 stycznia 2013 r., II AKzw 43/13, KZS 2013, nr 3, poz. 91; postanowienie SA we Wrocławiu z 13 października 2004 r., II AKzw 685/04, KZS 2005, nr 7-8, poz. 107; postanowienie SA w Krakowie z 13 grudnia 2001 r., II AKz 484/01, KZS 2001, nr 12, poz. 25; postanowienie SA w Krakowie z 27 czerwca 2000 r., II AKz 202/00, KZS 200, nr 7-8, poz. 42; postanowienie SA w Warszawie z 6 października 1998 r., II AKz 14/98, LEX nr 34819.

27 Zob. w tym zakresie wniosek (i zawarte w nim uzasadnienie) Rzecznika Praw Obywatelskich, który zwrócił się do Sądu Najwyższego — Izby Karnej o rozstrzygnięcie następującego zagadnienia prawnego: ,Czy rozstrzygając o warunkowym przedterminowym zwolnieniu sąd stosuje również ogólne dyrektywy wymiaru kary (art. 77 § 1 w zw. z art. 56 w zw. z art. 53 k.k.), czy też orzeka wyłącznie w oparciu o przesłanki wskazane w art. $77 \S 1$ k.k.?", https://www.rpo.gov.pl/sites/default/files/pytanie\%20prawne\%20 do\%20SN\%20warunkowe\%20zwolnienie.pdf (dostęp: 12 czerwca 2017).

Nowa Kodyfikacja Prawa Karnego 46, 2017

(C) for this edition by CNS 
możliwie szeroki. Oznaczałoby to więc, że decyzja o udzieleniu warunkowego przedterminowego zwolnienia nie może abstrahować od postanowień zawartych w art. 56 k.k. ${ }^{28} \mathrm{Z}$ drugiej natomiast strony, zwrócono uwagę na pewne względy systemowe, nakazujące dostrzec, że wspomniana regulacja art. 56 k.k. została umieszczona wśród przepisów poświęconych orzekaniu środków reakcji karnoprawnej w toku wyrokowania, rozważana instytucja warunkowego przedterminowego zwolnienia nie stanowi de facto zaś środka reakcji na popełnione przestępstwo, lecz na postępy resocjalizacyjne. W tym więc znaczeniu ,instytucja warunkowego przedterminowego zwolnienia nie wiąże się z orzekaniem o karze, ale z wykonywaniem kary i kieruje się swoistymi dyrektywami" 29 . W świetle tego ostatniego ujęcia:

Orzekanie co do przedterminowego zwolnienia z reszty kary pozbawienia wolności nie jest ponownym oznaczeniem kary za popełnione przestępstwo, ewentualnie jej łagodzeniem, ale jest racjonalnym stosowaniem środków penitencjarnych dla racjonalizowania kary, by nie pozbawiać wolności bez niezbędnej potrzeby i nie marnować społecznych nakładów na wykonywanie kary, co nie jest bez znaczenia, gdy wiele kar nie może być wykonywanych z braku środków po temu ${ }^{30}$.

W kontekście drugiego z przedstawionych stanowisk należałoby więc stwierdzić, że w ramach decyzji sądu o warunkowym przedterminowym zwolnieniu nie ma faktycznie miejsca na uwzględnienie celów kary, które legły u podstaw jej wymierzenia. Przyjmując w konsekwencji zaprezentowane w piśmiennictwie założenie, że cele wykonywania kary pozbawienia wolności nie stanowią de facto prostej kontynuacji dyrektywalnych celów z etapu wymiaru kary ${ }^{31}$, wypadałoby dopowiedzieć, iż względy sprawie-

\section{Ibidem.}

29 Wyrok TK z 10 lipca 2000 r., SK 21/99, OTK 2000, nr 5, poz. 144; zob. także uchwałę SN z 11 stycznia 1999 r., I KZP 15/98, OSNKW 1999, z. 1-2, poz. 1, w której podniesiono, że: „Ze swojej istoty warunkowe przedterminowe zwolnienie ma - niezależnie od tego, iż niektóre przepisy dotyczące tej instytucji zamieszczone zostały w Kodeksie karnym, nie zaś w Kodeksie karnym wykonawczym — charakter instytucji związanej nie z orzekaniem, a z wykonaniem kary pozbawienia wolności". Tak też w uchwale SN z 24 lutego 2006 r., I KZP 54/05, OSNKW 2006, nr 3, poz. 22.

30 Postanowienie SA w Krakowie z 8 kwietnia 2003 r., II AKZ 125/03, Legalis nr 59289.

31 T. Kalisz, Kara pozbawienia wolności z perspektywy rozważań teleologicznych dotyczacych wymiaru i wykonania kary, [w:] Prawo karne wykonawcze w systemie nauk

Nowa Kodyfikacja Prawa Karnego 46, 2017

(c) for this edition by CNS 
dliwościowe oraz ogólnoprewencyjne nie mogą stanowić miarodajnych kryteriów, pozwalających na ustalenie prognozy zachowania skazanego na wolności ${ }^{32}$. Na etapie wykonawczym te dwa ostatnie cele mogą co najwyżej znaleźć właściwą sobie ekspresję w ramach poprawnego zdiagnozowania pozytywnej prognozy kryminologicznej, warunkującej — od strony materialnej - skorzystanie z instytucji warunkowego przedterminowego zwolnienia ${ }^{33}$. Mając bowiem na uwadze specyfikę warunkowego przedterminowego zwolnienia ${ }^{34}$, nie sposób w tym miejscu pominąć faktu, że skorzystanie z omawianej instytucji probacyjnej mogłoby niekiedy rodzić w odczuciu społecznym przekonanie, iż sprawcy niesłusznie została „darowana" kara $^{35}$. $Z$ tego też względu udzielenie warunkowego przedterminowego zwolnienia wymaga oparcia na przekonujących argumentach, które pozwalałyby stwierdzić, że zastosowanie umiarkowanej ingerencji państwa w wolność osobistą sprawcy (w okresie próby) uzasadnia faktycznie pozytywny przebieg dotychczasowego procesu resocjalizacji ${ }^{36}$. Wnikliwe

kryminologicznych..., s. 239; M. Wielec, Znaczenie i rola systemów wykonywania kary pozbawienia wolności w resocjalizacji skazanego, [w:] Autorytet i godność stużb penitencjarnych a skuteczność metod resocjalizacji, red. J. Świtka, M. Kuć, I. Niewiadomska, Lublin 2004, s. 200. Zob. jednak S. Pawela, Kodeks karny wykonawczy. Praktyczny komentarz, Warszawa 1999, s. 17; J. Bafia, Podstawowe zasady prawa karnego wykonawczego, „Państwo i Prawo” 1968, nr 10, s. 532.

32 M. Kosiada, Glosa do postanowienia Sadu Apelacyjnego we Wroctawiu z dnia 13 października 2004 r., sygn. II AKzw 685/04, „Prokuratura i Prawo” 2007, nr 5, s. 169.

$33 \mathrm{~W}$ orzecznictwie podkreśla się przy tym, że: „Nie wszystkie okoliczności wymienione w art. 77 § 1 k.k. muszą zaistnieć kumulatywnie, niemniej jednak obowiązkiem sądu jest dokonanie kompleksowej ich analizy i dopiero wówczas sąd winien formułować względem skazanego prognozę społeczno-kryminologiczną" - postanowienie SA w Lublinie z 29 sierpnia 2012 r., II AKzw 866/12, LEX nr 1293502. Zob. również postanowienie SA w Krakowie z 8 marca 2012 r., II AKzw 113/12, LEX nr 1169414.

34 Zob. postanowienie SA w Krakowie z 27 czerwca 2000 r., II AKz 214/00, LEX nr 42967, w którym podniesiono, że: „Zasadą jest odbycie kary w całości, a ulgi w tym są wyjątkiem stosowanym, gdy jest to sprawiedliwe, więc zarówno zasłużone, jak celowe".

35 M. Niełaczna, Warunkowe przedterminowe zwolnienie skazanych na kary skrajnie dlugie. Prawo do drugiej szansy, [w:] Dlugoterminowe kary pozbawienia wolności w teorii i w praktyce, red. W. Zalewski, Gdańsk 2015, s. 216; R. Skarbek, Warunkowe przedterminowe zwolnienie z odbycia kary dhugoterminowej - problem prawny czy spoteczny, [w:] Dlugoterminowe kary pozbawienia wolności w teorii i w praktyce..., s. 269.

${ }^{36}$ Trudno przy tym nie zgodzić się z przekonaniem, że: ,Prognoza społeczno-kryminologiczna — jak każda inna prognoza, będąca jedynie przewidywaniem przyszłych

Nowa Kodyfikacja Prawa Karnego 46, 2017

(C) for this edition by CNS 
przeanalizowanie przesłanek, utwierdzające w możliwości skorzystania z omawianej instytucji, powinno w konsekwencji zapewnić, że zastosowany środek probacyjny nie będzie traktowany jako forma przedwczesnego zakończenia kary, lecz jako rozwiązanie, które jedynie stwarza szanse na odbywanie jej w warunkach wolnościowych. Orzeczenie kary pozbawienia wolności i częściowe jej wykonanie nie powinno bowiem pozostawiać

w świadomości społecznej odczucia, że sprawca uniknął należnej mu kary i że dobro, które on naruszył przestaje być we właściwy sposób chronione. Takie zaś odczucie — jak zasadnie wskazano w piśmiennictwie — może powstać w szczególności wtedy, kiedy stosuje się warunkowe przedterminowe zwolnienie w stosunku do osób, których czyn silnie utkwił w świadomości społecznej ${ }^{37}$.

Wobec powyższych słów trudno byłoby zatem rozproszyć podejrzenia, że wątpliwa wartość prewencyjna oraz społecznie integrująca omawianej instytucji probacyjnej mogłaby ujawnić się zwłaszcza wówczas, gdy wskutek nieprawidłowo ustalonej prognozy kryminologicznej ${ }^{38}$ znalazłaby ona zastosowanie wobec cynicznych sprawców tzw. medialnych przestępstw, których rzekomo przykładna postawa wynikałaby wprost nie z krytycznej autorefleksji, lecz z czystego wyrachowania i kalkulacji.

\section{Uwagi końcowe}

W przeprowadzonych rozważaniach zwrócono uwagę nie tylko na potrzebę odróżnienia celu kary od jej funkcji, lecz także na specyfikę

zdarzeń, jest ze swej istoty niepewna" — postanowienie SA we Wrocławiu z 12 stycznia 2005 r., II AKzw 1123/04, LEX nr 188236.

37 W. Wróbel, A. Zoll, Usprawiedliwienie karania (założenia systemu wymiaru kary w przysztym kodeksie karnym), [w:] O prawo karne oparte na zasadach sprawiedliwości, prawach człowieka i miłosierdziu, red. A. Strzembosz, Lublin 1988, s. 260.

38 W tym miejscu warto jednak wspomnieć o swoistych trudnościach, związanych z ustalaniem prognozy kryminologicznej. Trafnie więc stwierdza B. Hołyst, że: „Przedstawienie problematyki prognozy kryminologicznej w sposób jasny i pozbawiony sformułowań wieloznacznych staje się zadaniem niezwykle trudnym. Trudność tę potęguje m.in. brak powszechnie akceptowanego w kryminologii słownictwa z dziedziny prognostyki. W wielu przypadkach bowiem ma miejsce posługiwanie się swoistym żargonem, będącym w zasadzie mieszaniną terminów przyjętych $\mathrm{z}$ wielu dyscyplin, z których kryminologia korzysta lub z którymi graniczy" — B. Hołyst, Podstawy i zakres indywidualnej prognozy kryminologicznej, „Probacja” 2013, nr 1, s. 5.

Nowa Kodyfikacja Prawa Karnego 46, 2017

(C) for this edition by CNS 
zadań, jakie stawia się przed karą na etapie wymierzania oraz wykonywania. Na przykładzie kary pozbawienia wolności starano się podkreślić, że na etapie wykonawczym powierzone tej karze cele ulegają de facto zawężeniu (w porównaniu do etapu wymiaru kary), ograniczając się do urzeczywistnienia względów o charakterze indywidualnoprewencyjnym. Dokonane w niniejszym opracowaniu ustalenia skłaniają ponadto do wysunięcia wniosku, że ustawowo zakreślona pozycja szczególnoprewencyjnego celu przy orzekaniu warunkowego przedterminowego zwolnienia z odbycia reszty kary pozbawienia wolności powoduje, iż przy stosowaniu tego środka probacyjnego pozostałe cele karnomaterialne (których uwzględnienia prima facie wymagałaby treść art. 56 k.k.) muszą również ustąpić miejsca wspomnianym względom indywidualnoprewencyjnym ${ }^{39}$. Za takim też stanowiskiem opowiedział się 7-osobowy skład Sądu Najwyższego, uznając trafnie, że:

Podstawę orzekania o warunkowym przedterminowym zwolnieniu z odbycia reszty kary pozbawienia wolności stanowią kryteria określone w art. $77 \S 1$ k.k., nie są natomiast przesłankami rozstrzygania $\mathrm{w}$ tym przedmiocie dyrektywy wymiaru kary określone w art. 53 k.k., art. $54 \S 1$ k.k. oraz art. 55 k.k. (art. 56 k.k. $)^{40}$.

Przyjęty kierunek wykładni nie wiąże się przy tym z koniecznością ingerencji ustawodawczej w treść obowiązującej regulacji art. 56 k.k., pozwalającej przecież na „odpowiednie” stosowanie przepisów dyrektywalnych (determinujących wymiar kary) do ,innych środków przewidzianych w tym kodeksie" (do których zalicza się instytucję warunkowego przedterminowego zwolnienia). Należy wszak przypomnieć, że klauzula „odpowiedniego” stosowania pociąga za sobą w istocie trójwariantowość interpretacji, co w rezultacie prowadzi do wniosku, że: 1) przepis odniesienia może znaleźć zastosowanie wprost, 2) przepis odniesienia będzie wymagał dokonania pewnych modyfikacji, 3) przepis odniesienia nie znajdzie zastosowania z uwagi na niemożność jego zastosowania w ramach regulacji, na którą wskazuje przepis odsyłający ${ }^{41}$. Mając za-

39 K. Postulski, Kodeks Karny Wykonawczy. Komentarz, Warszawa 2014, s. 416.

40 Uchwała SN z 26 kwietnia 2017 r., LEX nr 2275714.

41 W orzecznictwie zwrócono uwagę, że ,przepis, który ma być odpowiednio stosowany, jest źródłem normy kierowanej do dwóch zakresów odniesienia. Pierwszy z nich reguluje instytucję prawną, z którą przepis odesłania jest bezpośrednio związany. Drugi zakres odniesienia obejmuje regulację innej instytucji, przy której normowaniu zamiesz-

Nowa Kodyfikacja Prawa Karnego 46, 2017

(C) for this edition by CNS 
tem na uwadze trzeci z wariantów wykładni klauzuli „odpowiedniego" stosowania, wypadałoby w tym miejscu skonkludować, że postanowienia wynikające z art. 56 k.k. mogą w istocie nie znaleźć zastosowania w określonym przypadku, jeżeli przemawiałaby za tym właśnie specyfika danej materii. W kontekście powyższych ustaleń można skonstatować, że zasygnalizowaną w ten sposób odrębnością wyróżnia się niewątpliwie omawiana instytucja probacyjna w postaci warunkowego przedterminowego zwolnienia.

Nie tracąc jednocześnie z pola widzenia zwłaszcza ogólnoprewencyjnych walorów prawidłowego stosowania przepisów karnowykonaw$\mathrm{czych}^{42}$, należy zastrzec, że dominacja celu indywidualnoprewencyjnego nie oznacza wszak, iż

przy podejmowaniu decyzji o warunkowym zwolnieniu względy ogólnoprewencyjne kary zupełnie przestają się liczyć, ale nabierają innego znaczenia. Gdy bowiem w wyniku oddziaływań resocjalizacyjnych okazuje się, że po stronie skazanego istnieje pozytywna prognoza społeczno-kryminologiczna, wymagana jest racjonalizacja kary, by nie pozbawiać wolności bez niezbędnej potrzeby nie tylko w imię respektowania zasady

czono przepis odsyłający. Treść normy funkcjonującej w pierwszym zakresie odniesienia daje się ustalić wprost z brzmienia przepisu odesłania. Natomiast przeniesienie tej normy poza macierzysty zakres regulacji odbywa się z założonym przez ustawodawcę dostosowaniem do drugiego zakresu odniesienia, dopuszczonym formułą »odpowiedniego« stosowania przepisu" - uchwała SN z 30 stycznia 2001 r., I KZP 50/00, OSNKW 2001, nr 3, poz. 16. Zob. także uchwała SN z 6 grudnia 2001 r., III CZP 41/00, OSNCP 2001, nr 4, poz. 57; wyrok SN z 17 stycznia 2013 r., III CZP 57/12, LEX nr 1321173; wyrok SA w Rzeszowie z 30 września 2015 r., III AUa 478/15, Legalis nr 1372768; wyrok NSA z 14 lutego 2013 r., II FSK 1789/11, LEX nr 1358261; wyrok NSA z 17 maja 2013 r., I FSK 444/13, LEX nr 1369535; wyrok WSA w Białymstoku z 9 kwietnia 2009 r., II SA/ Bk 15/09, Legalis nr 176852. Zob. również J. Nowacki, Studia z teorii prawa, Kraków 2003, s. 459; M. Świetlicka, ,Odpowiednie” stosowanie kodeksu postępowania karnego w sprawach o przestepstwa i wykroczenia skarbowe, „Prokuratura i Prawo” 2006, nr 10, s. 71; A. Błachnio-Parzych, Przepisy odsyłajace systemowo (Wybrane zagadnienia), „Państwo i Prawo” 2003, nr 1, s. 49.

42, ,...] odbywanie kary pozbawienia wolności jest w sposób immanentny związane z licznymi ograniczeniami i niedogodnościami, a obowiązkiem Skarbu Państwa — jako podmiotu odpowiedzialnego $\mathrm{w}$ ramach tzw. imperium za realizację polityki penitencjarnej jest jedynie zapewnienie osadzonym ustawowo określonych standardów" — wyrok SA w Łodzi z 6 marca 2013 r., I ACa 1212/12, LEX nr 1305965. 
humanitaryzmu, ale i unikania ponoszenia zbytecznych społecznych nakładów na wykonanie kary ${ }^{43}$.

$\mathrm{Z}$ powyższego wynika zatem, że — oceniane niejako post factum — prawidłowe stosowanie regulacji karnowykonawczych może sprzyjać socjopedagogicznemu osiągnięciu efektu internalizacji norm prawnych, a tym samym służyć budowaniu i utrwaleniu społecznego zaufania do wymiaru sprawiedliwości ${ }^{44}$.

\section{Purpose(s) of execution of imprisonment and release on licence (comments to the resolution of the Supreme Court of 26 April 2017, I KZP 2/1)}

Summary

This article brings attention not only to the need for a distinction between penalty and its functions, but also to the nature of the tasks posed before the penalty at the stage of imposing and executing the penalty. Based on the example of imprisonment, it has been proven that at the stage of execution the assigned to it objectives become limited to the completion of the reasons of the individual-preventive nature. Further part of this study also relates to the Supreme Court resolution of 26 April 2017, which accurately pointed out that while adjudicating release on licence from the rest of the sentence, criminal purposes, present at the stage of imposing the penalty (referred to in chapter VI of the Criminal Code), must yield to individual-preventive reasons.

Keywords: purpose(s) of punishment, release on licence, judicial sentencing.

43 Postanowienie SA w Katowicach z 20 maja 2014 r., II AKzw 557/14, LEX nr 1548436.

${ }^{44}$ Zob. K. Buchała, [w:] K. Buchała, A. Zoll, Kodeks karny. Część ogólna. Komentarz do art. 1-116 Kodeksu karnego, Kraków 2001, s. 416. 